\title{
THE COMMUNITY HOUSING PLAN: THE ROLE OF CAPACITY IN CANADIAN
} ON-RESERVE HOUSING POLICY

By:

\author{
Kristen Harder \\ B.A Urban Studies, University of Calgary 2013
}

\author{
A Major Research Paper \\ presented to Ryerson University \\ in partial fulfillment of the requirements of the degree of: \\ Master of Planning \\ in \\ Urban Development
}

Toronto, Ontario, Canada, 2017

(C) Kristen Harder 2017 


\section{Author's Declaration}

I hereby declare that I am the sole author of this MRP. This is a true copy of the MRP, including any required final revisions.

I authorize Ryerson University to lend this MRP to other institutions or individuals for the purpose of scholarly research.

I further authorize Ryerson University to reproduce this MRP by photocopying or by other means, in total or in part, at the request of other institutions or individuals for the purpose of scholarly research.

I understand that my MRP may be made electronically available to the public. 


\title{
THE COMMUNITY HOUSING PLAN: THE ROLE OF FIRST NATION CAPACITY IN CANADIAN ON-RESERVE HOUSING POLICY
}

\author{
Kristen Harder 2017 \\ Master of Planning \\ in \\ Urban Development \\ Ryerson University
}

\begin{abstract}
:
On-Reserve Housing Policy is failing First Nation communities across Canada as it appears unable to meet the complex housing needs of First Nations people, or effectively manage the operation of housing systems on reserve. This paper explores whether a relationship exists between the ability of First Nations to develop and implement a Community Housing Plan (CHP) and capacity development on-reserve. It does this by questioning whether on-reserve housing policy has created the appropriate administrative, financial and governance capacity to support the successful implementation of Community Housing Plans onreserve. The research uses qualitative methodology, reviewing literature and seven reports that explore Indigenous history in Canada and Canadian On-Reserve Housing Policy. The findings contemplate the wider implications of On-Reserve Housing Policy when First Nation capacity is not supported by the Federal Government, and the role of planning in the decolonization of Indigenous housing and policy.
\end{abstract}

Key Words:

First Nations housing, planning, on-reserve housing policy, First Nations capacity, Canada 


\section{Acknowledgments}

I extend my sincere gratitude to my supervisor Dr. Shelagh McCartney for her guidance in this research and for challenging me to think critically about the world we live in. Without her valuable insight and encouragement to explore a new field these pages would be blank. I would also like to thank Jeffrey Herskovits for his knowledge and support throughout this process.

I would like to extend my appreciation to colleagues and friends at Ryerson with whom many memories were made during early morning meetings or over endless coffees, allowing me to share my ideas, good or bad.

My Mom deserves a special thanks, withstanding long breathless phone calls as I became inspired and grew my passion around this topic, and Dad who I could always turn to for reason and perspective.

Most importantly I would like to acknowledge my Fiancé Trevor, whose relentless motivation and positivity brought light and laughter to the journey. 


\section{Table of Contents}

Author's Declaration.......................................................................................................

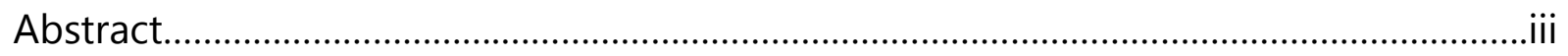

List of Figures........................................................................................................

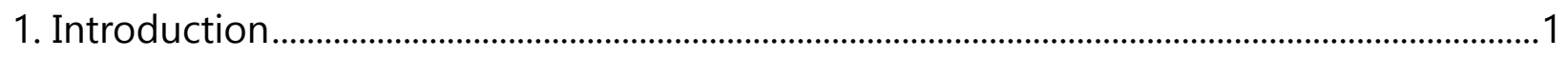

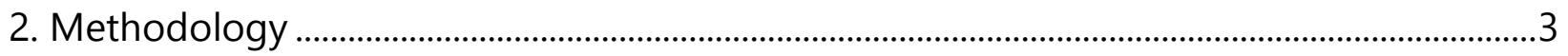

2.1 Guiding Research Questions ..............................................................................................

2.2 Qualitative Research Methods...........................................................................................

2.3 A Note on Indigenous and First Nation Terminology …………………………….. 10

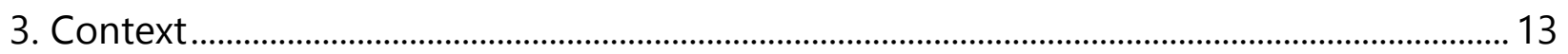

3.1 A Brief History of the Crown Relationship to First Nations....................................... 13

3.2 It's Not Over: The On-Reserve Housing Crisis ............................................................. 15

3.3 Federal Reaction to the Housing Crisis .................................................................... 16

3.4 Early Calls for On-Reserve Capacity and Self-Governance....................................... 18

4. Community Based Housing Programs............................................................................................ 22

4.1 Community Housing Plans: A Tool to Achieve Self-Governance? ?......................... 24

4.2 Discussing Capacity for Housing Systems On-Reserve............................................ 26

- Administrative Capacity............................................................................................ 26

- Funding Capacity ............................................................................................................. 28

- Governance Capacity ........................................................................................................ 31

4.3 The Big Letdown of Federal Support .............................................................................. 33

4.4 A Critique of the Community Housing Plan ……………………………………...... 34

5. Decolonizing On-Reserve Policy \& Planning ………………………………………................. 39

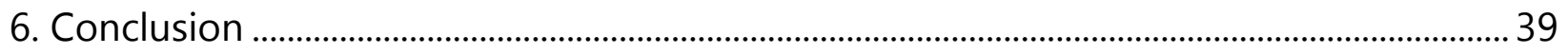

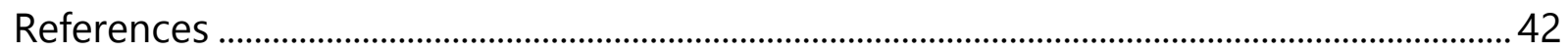

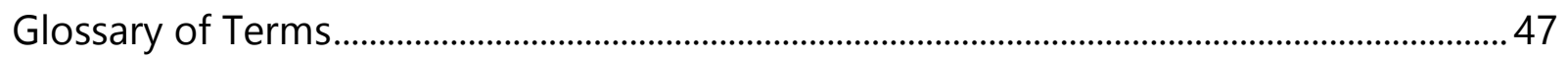




\section{List of Figures}

Figure 2.2.1 Policy Review Isolated Themes ……………………………………………….....

Figure 2.2.2 Pre 1996 Policy Report Recommendations .............................................................

Figure 2.2.3 Isolated Terminology from Report Recommendations ..........................................7

Figure 2.2.4 Founding Elements of the 1996 On-Reserve Housing Policy.............................8

Figure 2.2.5 Post 1996 Policy Report Recommendations.........................................................9

Figure 4.0.1 Establishing a Community Based Housing Program ........................................22

Figure 4.1.1 Establishing a Community Based Housing Plan .....................................................26 


\section{Introduction}

Inadequate, outdated, unlimited potential. Terms that could describe the physical living conditions of thousands of First Nation Peoples living on reserves in Canada. These terms could also be used to describe federal housing policies that administer housing programs and dwelling units on these same reserves. Inadequate, outdated, unlimited potential. First Nations continue to tolerate the direct involvement of the Canadian federal government which has established itself firmly in First Nation affairs. One of the most apparent interventions is seen through the historical changes to Indigenous settlement patterns with the creation of the reserve system. Through the 1867 Indian Act"the government set out its own vision of future Canada-First Nations relations: an aggressive colonizing project of assimilation not only of First Nations in those territories but of all First Nations throughout the nation" (Milloy, 2008). The history of home and community as a central point of colonial interaction has come at the great expense of Indigenous culture and well-being, altering their relationship to land and social structure (Monk, 2013). This interaction led to a "re-imagined, attempted, resisted, and ultimately refashioned" (Perry, 2003) reorganization of First Nations society (Perry, 2003). OnReserve housing policy continues to perpetuate this colonial encounter by limiting Indigenous abilities to self-govern through regulations that define their homes and communities. There is a current call for a paradigm shift, in which policy and planning can be repositioned to instead play a leading role in decolonizing of housing on reserve. If developed alongside First Nations, housing systems, provision and policy may become tools which hold the unbound potential to decolonize of the home. 
Community Housing Plans (CHP) are a founding component of the 1996 Federal On-Reserve Housing Policy operating on reserves. Yet, they are often found incomplete, outdated, uncomplied with, or simply do not exist in many communities (Indigenous and Northern Affairs Canada, 2008). Community Based Housing Plans are a responsibility downloaded from the federal government to First Nation communities. Community Housing Plans fulfill only one of several steps required to develop a Community Housing Program, a policy mandate through which funds for housing related activities and capacity development in the community are received. To create and manage a multi-year Community Housing Plan a significant level of administrative, financial and governance capacity is required. Despite this, appropriate capacity often not present on reserves nor its development supported by federal agencies.

This paper employs Community Housing Plans as a vehicle to explore the relationship between on-reserve capacity and a First Nations ability to take ownership of community planning onreserve. This research questions whether the 1996-On Reserve Housing Policy guiding housing systems on reserve has fostered or limited processes of decolonization through the mandate of complex housing plans. Community Housing Plans create an avenue for discussing the wider implications of on-reserve housing policy if First Nations are not provided with appropriate capacity to implement or manage local housing systems. In this context these implications may be contributing to the widespread housing crisis on reserve communities. This research implores that the conversation surrounding the role of federal housing policy in housing on reserve remain at the forefront of Indigenous and Planning studies, and current policy processes questioned. 


\section{Methodology}

The inspiration for this paper emerged from a desire to understand why the housing crisis on many reserve communities continues to persist despite the involvement of federal housing policy. Preliminary research of on-reserve housing policy reveals an association between capacity and the ability of First Nations to take control over housing systems on reserve. Where capacity development has not been supported, communities experience limited access to administrative, financial and governance resources. As such, they generally lack the ability to properly implement federal housing policy on reserve as it is intended. In order to narrow the scope of my research and frame this argument, I developed a series of research questions.

\subsection{Guiding Research Questions}

The following questions served as a guide in my exploration of capacity and Community Housing Plans within First Nations housing policy. It is not my intent to develop objective or complete answers. Rather, the questions helped frame my thinking as I adopted a critical perspective of on-reserve housing policy. It is my hope that this research can contribute to future debate and research on this topic.

1. Did the history of housing policy on-reserve change the role of First Nation homes and settlement patterns through practices of colonization and assimilation?

2. Do current on-reserve housing policies and programs provide appropriate quantity and quality housing on First Nation reserves? Do they play a contributing role in the ongoing housing crisis? 
3. Does the successful implementation of Community Housing Plans rely on capacity development on reserve? Does a lack of capacity limit the ability of First Nations to enact federal housing policy as it was intended?

4. Does a discussion of capacity and Community Housing Plans on reserve lead to wider implications for federal on-reserve housing policy?

5. Is there a relationship between Community Housing Plans and the field of planning? If so, can this relationship become an opportunity to contribute to the de-colonization of housing policy?

\subsection{Qualitative Research Methods}

In order to explore these research questions I employed a qualitative methodology informed primarily by a literature and policy review. I establish historical links between Crown policies and First Nations to discuss the federal governments' coercive role in redefining First Nations governance structures and settlement patterns. Acknowledging this complex history is necessary to comprehend the political conditions leading to the first on-reserve housing policies. This history also reveals how on-reserve housing policy became an agent of colonization and assimilation of the First Nation Peoples in Canada. This infamous legacy remains pronounced in the literature that discusses contemporary issues with First Nation housing.

To establish a timeline for policy review I selected seven analytic reports assessing on-reserve housing policy. These reports provide insight into the condition of on-reserve housing prior to, and post the implementation of the current 1996 On-Reserve Housing Policy. This analysis allowed for the discovery and documentation of reoccurring themes shown in figure 2.2.1. 


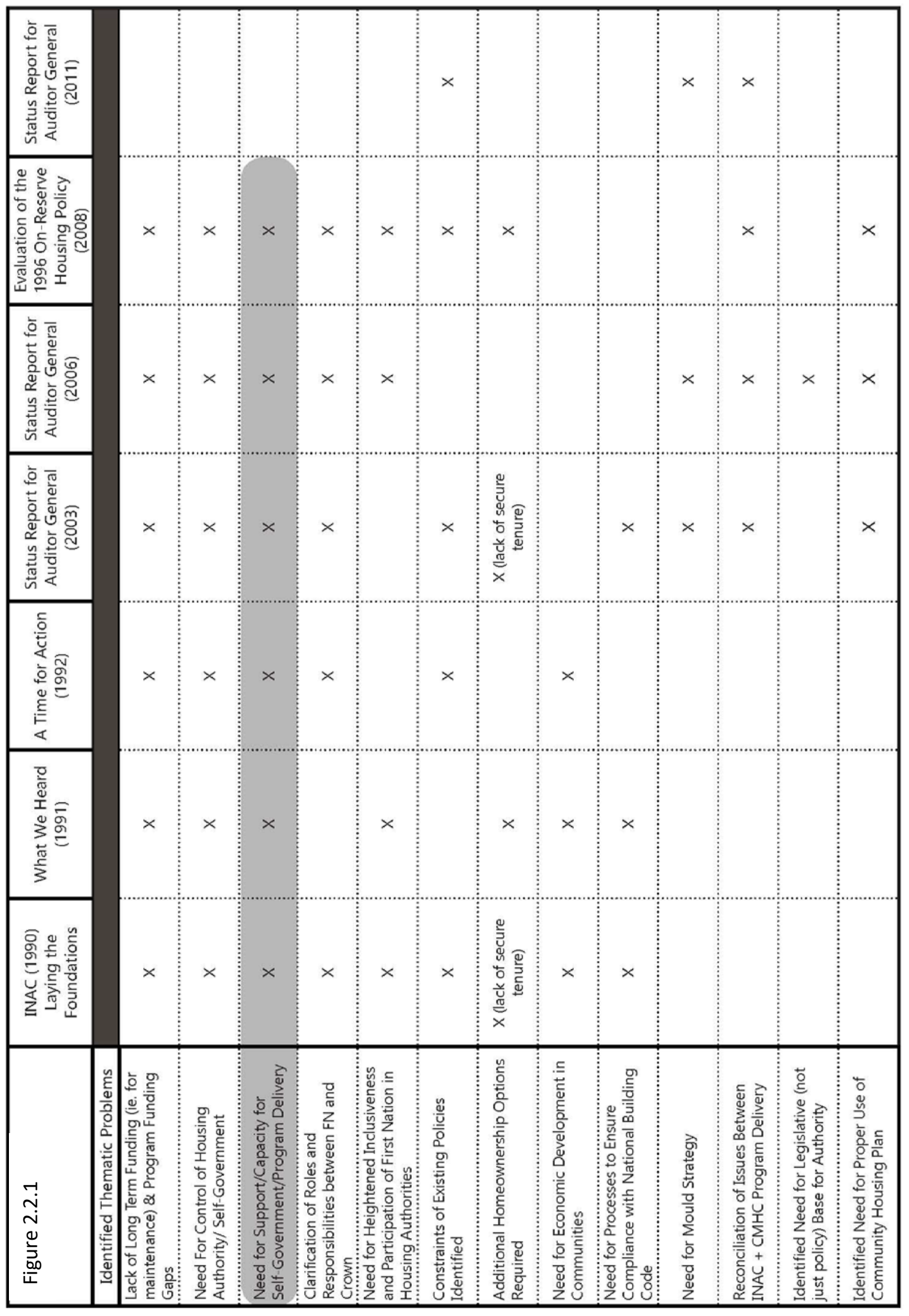


Though any of the discovered themes and relationships merit study, I chose to explore capacity. More specifically, the relationship of capacity to a First Nations ability to successfully implement programs from the 1996 On-Reserve Housing Policy. In this context capacity can be described as "the combination of people, institutions, resources, organizational abilities, authority, and practices that enable First Nations communities to reach their own goals" (Millette, 2011). The theme of capacity was chosen for its important role in all aspects of housing policy on reserve, including; administrative, financial, governance and federal contexts.

To isolate the theme of capacity I conducted a thorough review of the seven selected reports. Reports were reviewed within their important temporal context, written before or after the enactment of the 1996 On-Reserve Housing Policy. This exercise established a basic understanding of on-reserve housing and policy conditions within each context. Report objectives and recommendations were then catalogued linearly and examined for patterns of terminology and reoccurring themes. Though each report contains valuable information on several issues such as on-reserve health, education, and infrastructure; only recommendations which held a direct relationship to housing policy and programming were reviewed. Themes which appeared significant and re-occurred throughout the analysis were documented. Report recommendations submitted prior to the creation 1996 On-Reserve Housing Policy are highlighted in figure 2.2.2. These earlier reports illustrate historical housing conditions onreserve and concerns with previous housing policy. Most importantly they share important information about the desired direction of future policy. 
Figure 2.2.2

$1990 \begin{aligned} & \text { Laying the Foundations of a New On-Reserve Housing Program } \\ & \text { objective 1. Ensure meaningful Indian involvement in the } \\ & \text { development of federal on-reserve housing policies, and provide } \\ & \text { for direct Indian control of program design and delivery with } \\ & \text { appropriate government support and assistance }\end{aligned}$
$\begin{aligned} & \text { What we Heard. Report on the Rural and Native Housing Consultation } \\ & \text { Comments on Program Delivery and Administration Section 5.8 } \\ & \text { General Support for the need to move in this direction [community } \\ & \text { involvement] in a controlled and well-monitored fashion with } \\ & \text { adequate support }\end{aligned}$
$\begin{aligned} & \text { A Time for Action } \\ & \text { Affairs Canada (INAC) }\end{aligned}$
$\begin{aligned} & \text { Recommendation 1. Committee recommends that the Government } \\ & \text { of Canada transfer, in consultation with Aboriginal people, control of } \\ & \text { housing along with sufficient resources to Aboriginal people in order } \\ & \text { to ensure there is greater community control over the development } \\ & \text { and delivery of housing programs. Aboriginal people themselves } \\ & \text { should determine whether the appropriate delivery structures } \\ & \text { should be developed at the local tribal council, regional, territorial or } \\ & \text { national level }\end{aligned}$

Themes identified by compiling recommendations and objectives in the three reports submitted prior to the 1996 policy were distilled into key terms, shown in figure 2.2.3. These terms were then interpreted within modern policy language. Through this process the relationship between selfgovernance over housing policy and capacity emerges. First Nation capacity and self- governance became leading concepts of the OnFigure 2.2.3 Isolated Terminology Reserve Housing Policy, later released Report Recommendations (pre-1996 On-Reserve Housing Policy)

\author{
in 1996. Alongside Shared \\ Responsibility and Access to Private \\ Capital, First Nation Control and \\ Capacity Development are two of the \\ four founding four policy elements.
}
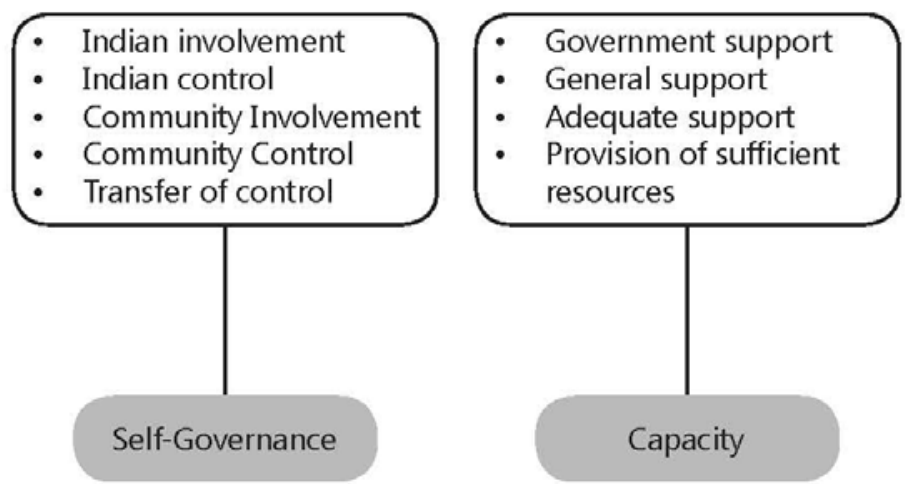
The founding elements of the 1996 On-Reserve Housing Policy are illustrated below in figure 2.2.4.

Figure 2.2.4

\section{Founding Elements of the 1996 On-Reserve Housing Policy}

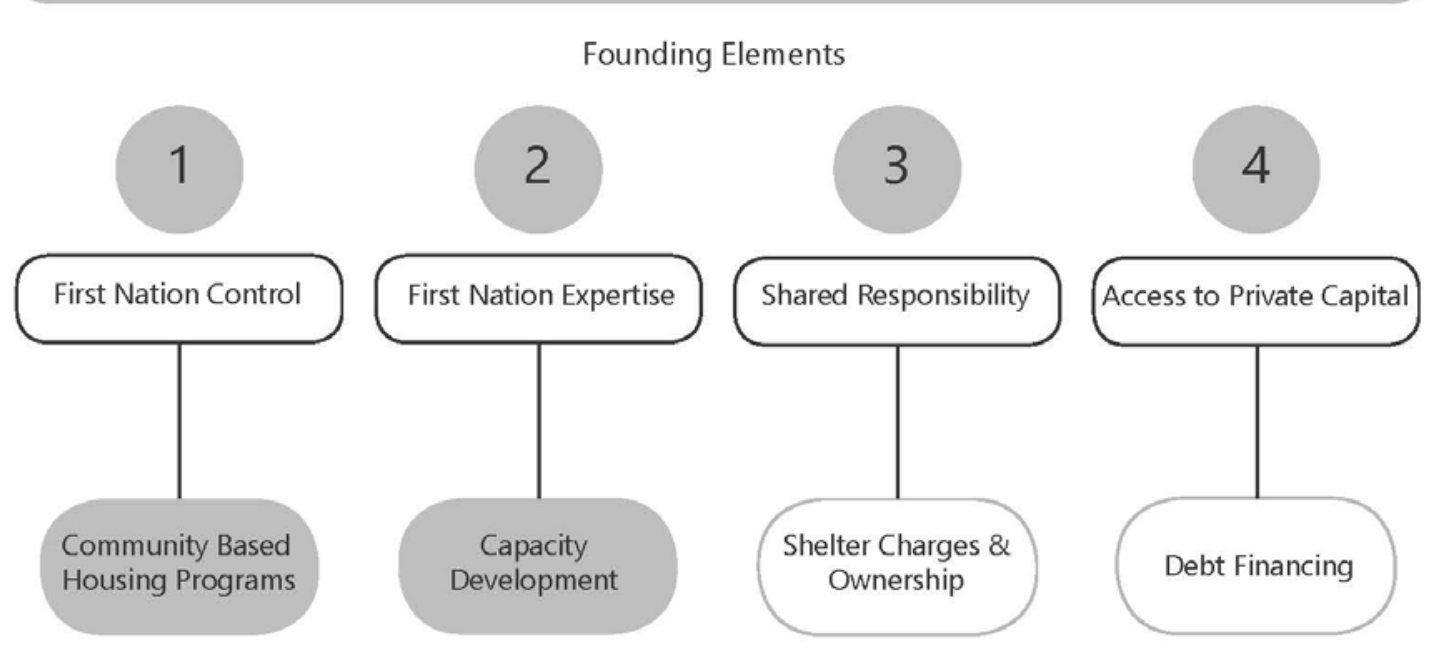

The 1996 On-Reserve Housing Policy proposed that Community Based Housing Programs, including multi-year Community Housing Plans be employed to transfer control of on-reserve housing systems to First Nations governance. First Nations were expected build their local housing and governance expertise by creating housing authorities. The efforts of First Nations to adopt and implement the program were supported by the federal government with a promise that capacity development would occur simultaneously on-reserve.

A thematic search of objectives and recommendations submitted in reports written after the implementation of the 1996 On-Reserve Housing Policy strengthened the argument that a relationship indeed exists between a First Nations ability to implement Community Housing Plans and access to necessary capacity (figure 2.2.5).

This methodology highlighted important themes and established critical links between them, narrowing the research scope and allowing for the establishment of preliminary conclusions. 
Figure 2.2.5

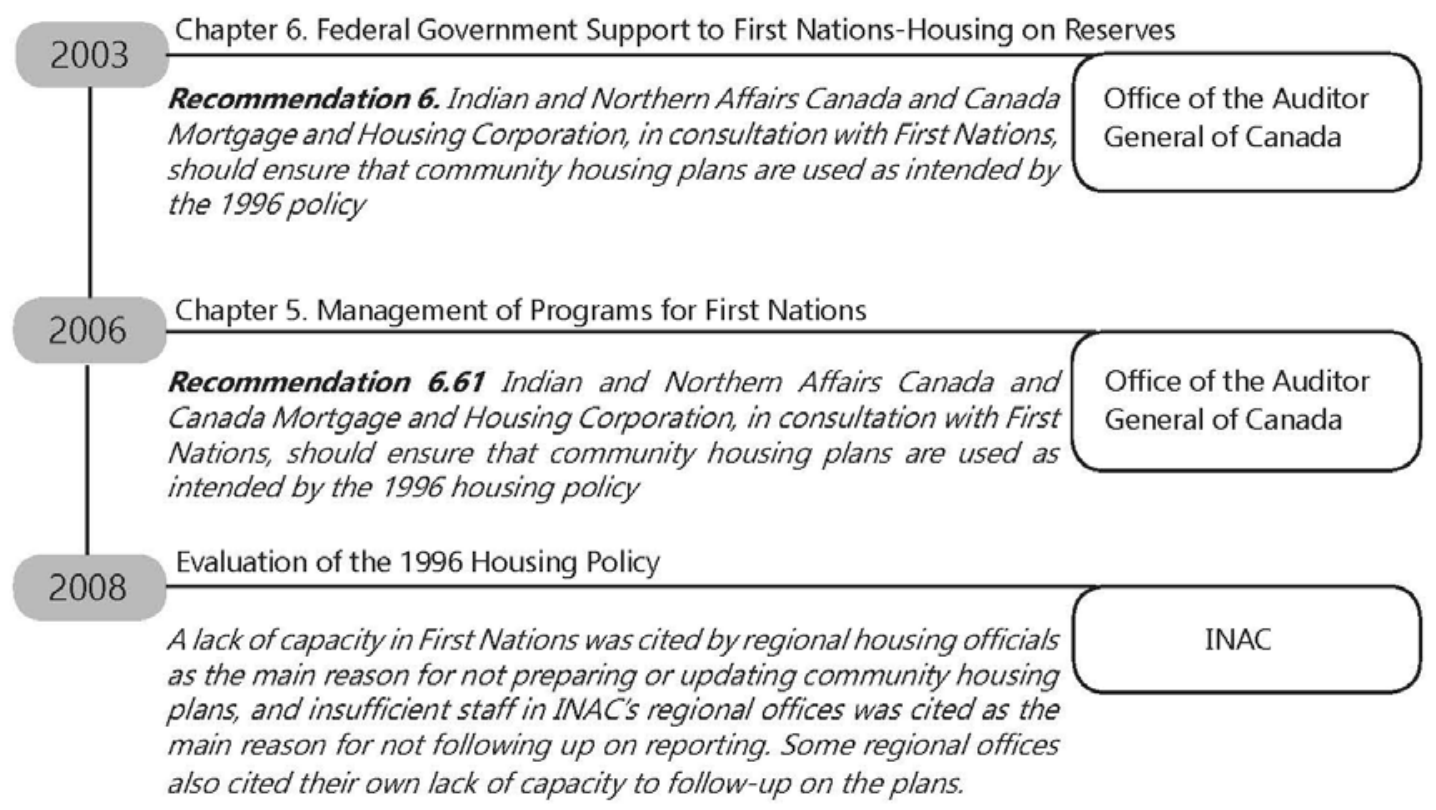

Next, I reviewed the steps required for a First Nation to establish, submit and maintain a

Community Housing Plan to deepen the connection between CHPs and capacity development. It became apparent that capacity plays an important role as it relates to housing policy on-reserve. It is an integral piece within administrative, financial, and governance contexts.

To ensure this policy review was grounded in relevant Indigenous and Planning theory, the academic literature exploring relationships between on-reserve housing policy, colonialism, assimilation and planning was reviewed. Prominent key terms and concepts guided this search including: self-determination, self-governance, capacity, on-reserve housing, and Indigenous planning. This literature bounded my research in a theoretical framework.

Acknowledging my limited knowledge of Indigenous culture and experiences, as well as my inherent bias as a white settler, texts and reports authored by First Nations themselves were reviewed to gain a better understanding of Indigenous perspectives. These readings were further supported with narrative literature on First Nations culture and heritage. 
Each component of this methodology informed the following discussion of the relationship between capacity development and Community Housing Plan implementation. Findings question the efficiency and success of the Community Housing Plan, and discuss if it can be

interpreted as an indicator of wider problems surrounding federal on-reserve housing policy.

Finally, to relate this work back to the field of planning, Community Housing Plans are considered for their use as an Indigenous planning tool, leading to a discussion of the opportunity for CHPs to play a role in the decolonization of housing policy.

\subsection{A Note on Indigenous and First Nation Terminology}

To write this research paper I utilize terminology found in modern literature authored by First Nations. Indigenous communities in Canada are incredibly diverse in their size, location and culture. There are approximately 630 First Nation communities and more than 50 identified nations (Indigenous and Northern Affairs Canada, 2016), therefore terminology is a subject receiving close review in the field of Indigenous study. At the risk of over simplifying terms used to describe First Nations it is my intent to establish my argument while minimizing opportunities for offense. I acknowledge that preferences for use of terminology can differ between First Nation Peoples, and that the use of terms in Canadian legislation and policy may still incorporate offensive terminology. For example, the term Aboriginal is omitted, where possible, unless used in direct discussion with its emergence as a term in 1982 with the Constitution Act when it was developed to describe descendants of the original inhabitants of North America (Indigenous and Northern Affairs Canada, 2016). The 1982 Constitution Act recognizes three groups of Aboriginal people - Indians, Metis, and Inuit. Acknowledging these are three separate 
peoples with unique heritages, languages, cultural practices and spiritual beliefs (Indigenous and Northern Affairs Canada, 2016).

This research predominantly adopts the use of the term First Nation Peoples, often used interchangeably with Indigenous Peoples to describe the diverse cultural First Nation groups in Canada who do not identify as Metis or Inuit (University of British Columbia , 2009). First Nation (s) is a term that came into common usage in the 1970s to replace the word "Indian" which today is widely found offensive (Indigenous and Northern Affairs Canada, 2016). Although First Nation is now a popular term it holds no legal definition, and most commonly it refers to Indigenous Peoples in Canada, both Status and non-Status (Indigenous and Northern Affairs Canada, 2016). A reserve generally refers to an area of land to which the Crown holds the legal title (Indigenous and Northern Affairs Canada, 2016) and are set apart for the use and benefit of an Indian Band (Indigenous and Northern Affairs Canada, 2016). Remote reserves are typically described as a First Nation Band that is located over $350 \mathrm{~km}$ from the nearest service centre having year round road access (Office of the Auditor General of Canada, 2006). These may be located within a special access zone, a geographic zone where a First Nation has no year-round road access to the nearest service centre for access to "supplies and equipment, a pool of semiskilled labour, at least one financial institution and government services" (Office of the Auditor General of Canada, 2006). A Band is a group of First Nation people for whose collective use and benefit reserve lands have been set apart or (Aboriginal Affairs and Northern Development Canada, 2011) declared for the purposes of the 1876 Indian Act (Aboriginal Affairs and Northern Development Canada, 2011). They typically consist of a governing Band council including a chief and several councilors (Aboriginal Affairs and Northern Development Canada, 2011). The 
members of First Nations Bands may share common values, traditions, languages and practices rooted in their ancestral heritage (Aboriginal Affairs and Northern Development Canada, 2011), however these cultural groupings are often generalized. It should not be assumed that those from large cultural areas always share the same culture and experiences (The Canadian Encyclopedia, 2016). Housing authorities are administrative bodies which exist on most reserves and are responsible for managing the planning, forecasting and day-to-day operations around housing or making recommendations to the chief and council on new or revised housing policies, programs and plans (Aboriginal Affairs and Northern Development Canada, 2011). These terms were employed based on their use in common Indigenous literature. As is the tendency of terminology in Indigenous studies, they may not be found entirely appropriate according to all perspectives or circumstances, a challenge which remains inherent to contributing literature in this field of study. 


\section{Context}

Prior to discussing the modern implications of housing policy and conditions on reserve, due process calls for a general understanding of relevant historical context. The Crown and First Nations have a long complex relationship defined by colonization and assimilation. Establishing this history creates a deeper understanding of the current housing crisis on reserves and leads to a discussion of how federal policy continues to be reflected in Indigenous communities.

\subsection{A Brief History of the Crown Relationship to First Nations}

The argument that the design and intent of on-reserve housing policy and planning practices in Canada reflects historical colonial and assimilative agendas has been thoroughly investigated in academic literature. Over time, "assimilation became the enduring justification for federal colonialism" (Milloy, 2008) through which Indigenous customs were conformed to western ideologies. Assimilation was achieved only when Indigenous Peoples "abandoned collective housing and adopted the Western styles thought to both represent and constitute European norms of domestic and familial life" (Perry, 2003). The Indian Act of 1867 became a legislative tool of control that directed First Nations to reserves and a breakdown of traditional governance structures (Indigenous and Northern Affairs Canada, 2016). The Act was controlling and coercive, working to "displace traditional forms of First Nations' governance in order to ensure a firm hold on the Indians and their lands" (Missens, 2008). As a result the traditional social, political and economic institutions of First Nations Peoples no longer exist as they once did (Missens, 2008). Families were driven from semi-nomadic lifestyles in remote villages to occupy permanent residences for access to federal resources and education for their children (Hill, 2010), and the sacred relationship between First Nations and the land was fundamentally altered with their 
permanent establishment on reserves (Hill, 2010). Designed by colonizers, reserves came to reflect western style communities and the westernized values they wanted First Nations to adopt (Perry, 2003). The colonial government also held the power to determine geographic boundaries of reserves through treaties to control the physical location of First Nation communities (Kyser, 2012). Ultimately, the reserve system was strategically designed with the intent of using land-use as a physical platform where powerful entities could undertake the eradication of Indigenous identity and culture (McCartney, 2016).

This narrative demonstrates that the intent of early federal government policies was to develop a land use system (reserves) designed to give the illusion that First Nations held control of their land, while encouraging a departure from Indigenous culture and governance systems through incentivized enfranchisement. As the "Indian" became enfranchised, that is, assimilated "he would take with him his share of the reserve. Therefore when all Indians were enfranchised, there would no longer be any Indian reserves" (Hutchins \& Hutchins, 2002). This assimilative series of events continues to cause severe and inter-generational damage to the cultural and physical well-being of First Nations on and off reserve. Assistance policies created as recently as the 1960s were modeled in a way that endorsed assimilation and support for First Nations moving away from reserves (Brant, 2000).

Though federal policy has been designed to deconstruct the culture of First Nation Peoples and sever their physical and spiritual relationship to the land, the persistence of reserve communities to remain on the lands they hold merits deep admiration. The recognition that reserves are not temporary, and will remain as long as First Nations continue to champion for their culture and land must be reflected in First Nation on-reserve housing policy. 


\subsection{It's Not Over: The Housing Crisis}

The insertion of colonial ideology in the design of historical on-reserve housing policy has revealed lasting effects on reserve communities. Though homes and communities typically reflect the cultural preference of the people living in them, dwellings and community layouts on reserves are largely representative of federal policy outcomes. Since the implementation of housing policies stemming from the mid-20th century lasting into the mid-1990s (Kyser, 2012), the built form of many First Nation communities are defined by individual dwellings and community structures not reflective of Aboriginal culture (Canada Mortgage and Housing Corporation, 2005). These buildings are a product of policies were designed and administered by two federal agencies, Indian and Northern Affairs Canada (INAC) and the Canada Mortgage and Housing Corporation (CMHC) (Kyser, 2012). The structures built were generally substandard, "typified by elevated plywood bungalows that do not provide adequate shelter or services"

(Kyser, 2012). Despite the diversity of cultural, geographic and socioeconomic factors, First Nations had a very minimal range of housing options (Kyser, 2012) which lacked any meaningful Indigenous perspective. It could be argued that by purposefully providing homes which are unsuitable to First Nation culture and structurally inappropriate for the physical environment, federal agencies were making active attempts to reduce the lifecycle of housing stock on reserve and encourage a move into urban centres.

The consequences of these negligent building practices were quick to emerge. By 1948 First Nations and Aboriginal leaders across Canada confirmed through a series of public reports that a housing crisis, both on and off reserve extended across all Canadian provinces (Belanger, 2016). Seventy years later, despite the millions of dollars allocated annually through CMHC and 
Aboriginal Affairs and Northern Development Canada (AANDC) to housing programs (Canada Mortgage and Housing Corporation, 2015), conditions continue to be significantly below the national average on First Nations reserves (Office of the Auditor General of Canada, 2011).

\subsection{The Federal Reaction to the Housing Crisis}

Explanations for the persevering housing crisis and suitable approaches to dealing with it are subjects of ongoing debate. What remains uncontested is the understanding that the crisis continues to hamper the health and well-being of many First Nation communities. The combination of "rapid population growth, inadequate funding, restrictive government policies, lack of home ownership and culturally appropriate housing designs" (MacTavish, Marceau, \& Optis, 2012) are all considered to be contributing factors. The federal governments' negligent reaction to the dire state of housing on-reserve was heavily documented by reports publicizing the housing crisis in throughout the early 1990's. Report findings describe the consequences of implementing inappropriate housing policies in First Nations communities, which had manifested into a housing crisis spanning the country. In 2011, Aboriginal Affairs and Northern Development Canada's (AANDC) estimated the housing shortage on reserve ranged from 35,000 to 40,000 units, however the Assembly of First Nations approximated the shortage to be much higher with an immediate need for approximately 85,000 units (Senate Canada, 2015). Future projections anticipate that the shortage will rise to a shocking 115,000 units by 2031 (Akin, 2016). The housing crisis may be hardest felt by small northern remote communities. According to the 2011 population census of all First Nations communities in Canada " $70 \%$ of First Nations reserves have less than 500 inhabitants" (Indigenous and Northern Affairs Canada, 2011) many of which are remote or special access (Office of the Auditor General of Canada, 2006). Their 
limited accessibility by year round air or winter ice road make the acquisition of suitable building materials and the expertise to build new homes logistically difficult and extremely expensive (Indigenous and Northern Affairs Canada, 2016). Should local resources be unavailable they are replaced with building materials imported from southern centres that cannot not properly withstand northern climates, leading to a quickened dilapidation of the existing housing stock (Canada Mortgage and Housing Corporation, 2005). Federal funding provided is not proportional to the funding required to the build sufficient housing stock needed to accommodate the thriving population of youth on reserves, a youth who are growing at double the Canadian average (Office of the Auditor General of Canada , 2003).

The combination of a high birth rate, growing shortage of existing homes, and very few new home builds has resulted in severe overcrowding on reserve (University of Manitoba, n.d.). Overcrowding has been proven to have a direct impact on physical health conditions due to mold contamination and lead to high numbers of homes that require major repairs or replacement (Senate Canada, 2015). Overcrowding also leads to lowered emotional, mental and spiritual health (Reading \& Wien, 2009) and creates increased opportunities for violence. Assaults related to family and domestic violence make up ten percent of reported injuries by Indigenous Peoples (First Nation Information Governance Centre, 2008).

To address the housing crisis on-reserve, housing policy must be re-designed to accommodate the physical, emotional and spiritual needs of First Nation communities. This requires that federal agencies judge the habitability of a home or community based off of the well-being of the inhabitants living inside them. 


\subsection{Early Calls for On-Reserve Capacity and Self Governance}

Early documentation of the housing crisis revealed three disconcerting findings. First the annual supply of homes being provided on reserve was not meeting replacement demand (Belanger, 2016). Second, older reserve homes were some of the poorest housing stock in Canada, and third, the "department of Indian Affairs and Northern Development had no specific plan to address the existing shortage" (Belanger, 2016). A change to the current approach to housing policy was inevitable and federal agencies began searching for policy alternatives. First Nations were consulted based on their participation in the previous program sparking a conversation around priorities areas to highlight in future policy.

Analysis of recommendations from reports evaluating historical on-reserve housing policy identify self-governance and capacity as emerging areas of importance to First Nations when considering future policy design.

\section{0}

- In INAC's report Laying the Foundations of a New On-Reserve Housing Program, a Discussion Paper First Nations expressed frustration that though involved in the administration of programs they were excluded in the design of programs and methods of implementation (Indigenous and Northern Affairs Canada, 1990). Greater First Nation control over housing on reserve was called for to grow self-governance and inclusivity in housing systems. To establish First Nation control it was proposed the government "recognize the authority of First Nations to deal with housing needs of their people, and 
transfer them added responsibility and appropriate resources for the design and delivery of on-reserve housing programs" (Indigenous and Northern Affairs Canada, 1990).

\section{1}

- Canada Mortgage and Housing Corporation (CMHC) initiated the Rural and Native Housing Consultation program to consult community members' using existing onreserve housing programs to gain insight into priority areas by gathering local recommendations (Canada Mortgage and Housing Corporation, 1991). First Nations expressed the desire to have a range of delivery, administrative, and managerial options for on-reserve programming (Canada Mortgage and Housing Corporation, 1991). It was requested that future transfers of responsibility for housing systems should occur slowly, with the recognition that some municipal Bands/Councils may never be perfectly equipped or capable of undertaking full responsibility (Canada Mortgage and Housing Corporation, 1991).

\section{2}

- The House of Commons' Standing Committee on Aboriginal Affairs commissioned the first comprehensive study of Aboriginal housing in A Time for Action (Belanger, 2016). This report revealed a startling one half, or approximately 35,000 of reserve homes were unfit for occupancy, and there was an immediate need for 21,700 new housing units (Belanger, 2016). An additional 6,700 required replacing, and 44,500 required substantial repairs (Belanger, 2016). Fourteen recommendations were submitted in A Time for Action that demanded a response to issues of funding, governance and capacity. The overall 
aspiration of local community responses was the establishment of First Nation control of housing systems coupled with a transfer of appropriate resources (Shneider, 1992).

This series of report findings illustrates how on-reserve housing policy was failing First Nation communities across Canada. The federal governments typical delivery of "ad hoc housing policies were unable to accommodate the demands of reserve communities, whose growing populations outstripped local housing assets" (Belanger, 2016).

The response of the federal government to First Nations who were ambitiously lobbying for a transfer of on-reserve housing to community control (where appropriate) and with adequate support was an updated on-reserve housing policy enacted in 1996. The 1996 On-Reserve Housing Policy was revered, thought to possess solutions plaguing housing issues on reserve. Its new powers would:

X Reduce restrictions of previous policy

$\$$ Solve funding related problems

Develop programs for capacity development on all participating reserves (Indigenous and Northern Affairs Canada, 2008)

(1) Gradually transfer responsibility for housing systems to Band councils and on-reserve housing authorities through involvement of First Nations participation in planning community housing, guided by Community Based Housing Programs (Koeck, 2000).

Despite the policy's intent, twenty years later many issues on-reserve remain unsolved. A major weakness of this policy is its standardized approach which fails to recognize the diversity of First Nations communities, particularly their size, location, capacity and resource availability. Elements of the policy that are advocated and funded federally typically fall within formulaic and top down processes and do not consider alternative approaches (Millette, 2011) that may be more 
congruent with First Nations. Though all participating First Nation communities are expected to fulfill the same requirements of the policy to be eligible for future support and funding opportunities, they are not all equally capable. First Nations were expected to enact policy requirements with very little upfront administrative, financial and federal support. Evidence of this can be found by inspecting one of the four founding policy elements more closely; the Community Housing Program. 


\section{Community Based Housing Programs}

The Community Based Housing Program was viewed as an opportunity for participating First Nation Bands to re-imagine the future of their communities, strengthen local accountability (Koeck, 2000), and "provide a process by which community members can participate in the design of local policies, programs and plans" (Koeck, 2000). Participation of First Nations in the Community Housing Program held the promise that housing systems developed would be individualized to meet the unique needs of each community (Koeck, 2000). An additional incentive promised added flexibility in the use and extended terms of funding (Koeck, 2000). Figure 4.0.1 illustrates the steps necessary to complete a Community Housing Program.

Despite the intent of involving First Nations in community planning as an attempt to transfer control over housing systems to community governance, Community Based Housing Programs have not been universally successful on reserves that experience limited capacity. This observation was further explored by selecting one element of the Community Housing Program for further review. The Community Housing Plan was chosen for its direct relationship to the field of community planning and its reoccurrence throughout reports evaluating the underperformance of the 1996 On-Reserve Housing Policy. 
Figure 4.0.1

\section{Establishing a Community Housing Program}
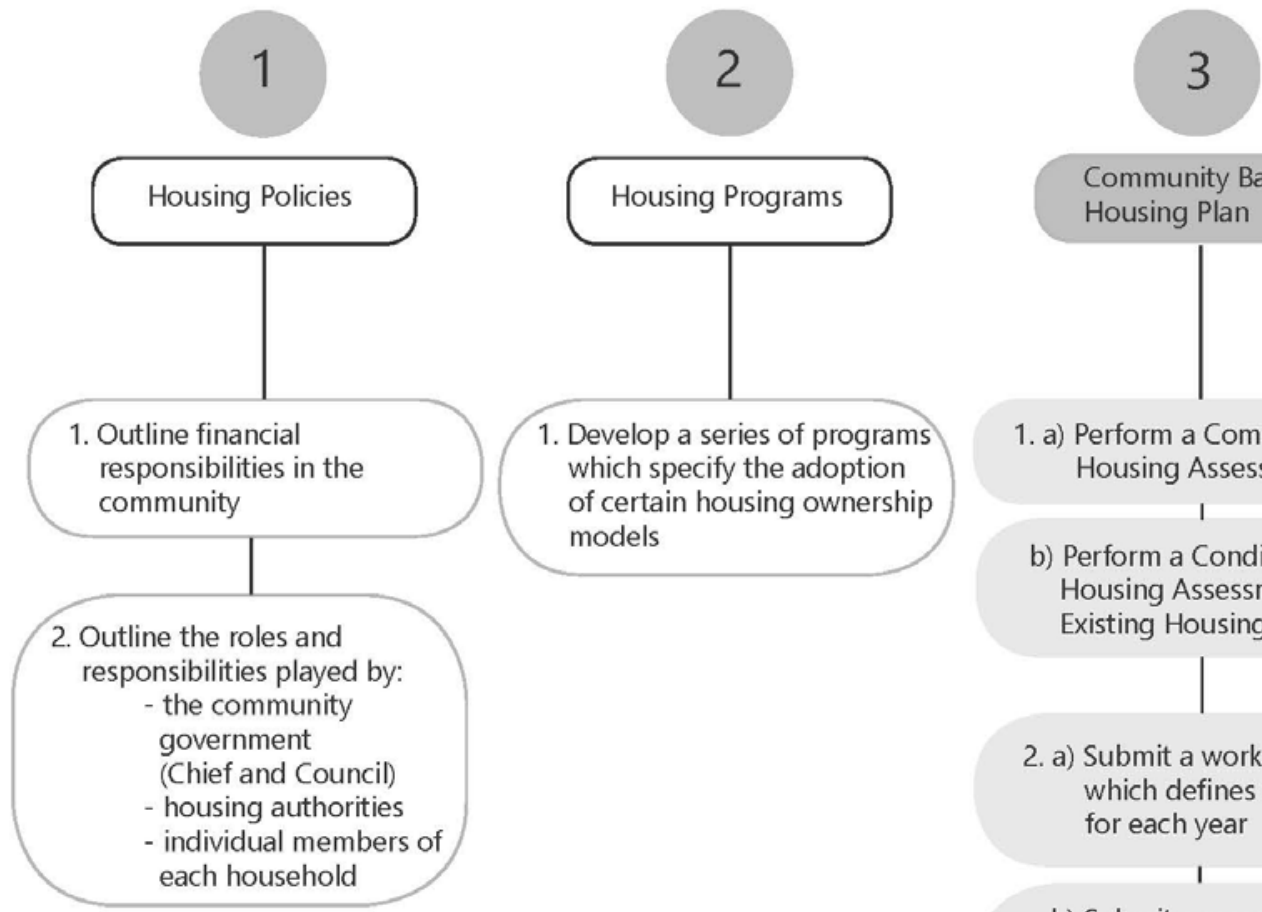

Community Based Housing Plan

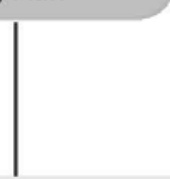

1. a) Perform a Community Housing Assessment

b) Perform a Conditional Housing Assessment of Existing Housing

2. a) Submit a work plan which defines tasks for each year

b) Submit a resource plan which outlines the financial capacity of a Band

3. Indicate how housing activities will be linked with training, job creation \& business development 


\subsection{Community Housing Plans (CHP): A Tool to Achieve Self-Governance}

The embrace of First Nation self-governance through Community Housing Plans shows a movement away from federal ideologies of assimilation through civilization (Belanger, 2016). However the devolution of responsibilities to local First Nations (Belanger, 2016) without providing the necessary capacity or resources to manage them has not led to the establishment of local governance or improved housing conditions on many remote First Nation communities. Following is a discussion of the justification for Community Housing Plans, steps First Nations must undertake to create and implement them, as well as and the types of capacity they require.

Community Housing Plans were intended to contribute to the success of the 1996 On-Reserve Housing Policy by shifting responsibility for community planning initiatives onto First Nation communities. The intent was to use Community Housing Plans as opportunities for selfgovernance over housing systems. There is however, little evidence that substantial success has been had in achieving this goal. Conversely, there is a convincing argument that Community Housing Plans are in fact not functioning as they were intended to. This evidence is found in two federal audit reports released in 2003 and 2006. The Audit branch of the federal government adopts an unbiased view to examine "the delivery of on-reserve housing programs that influence the social, economic, and environmental conditions faced by Aboriginal people and their communities," (Office of the Auditor General of Canada , 2003). The Audit branch also determines whether roles, responsibilities and expected results associated with on-reserve housing programs are defined (Office of the Auditor General of Canada, 2003). INAC and $\mathrm{CMHC}$ were the focus of the audit as "the two main federal organizations that assist First Nations in meeting their on-reserve needs" (Office of the Auditor General of Canada , 2003). The 
auditor general reports catalogue conditions on reserve, analyze the performance of policy elements and provide recommendations for the consideration of INAC and CMHC. In both 2003 and 2006 Community Housing Plans were listed in recommendations submitted to these agencies. Though the recommendations outlined in figure 2.2.5 signify there problems with the implementation of Community Housing Plans, further investigation reveals the causal factors.

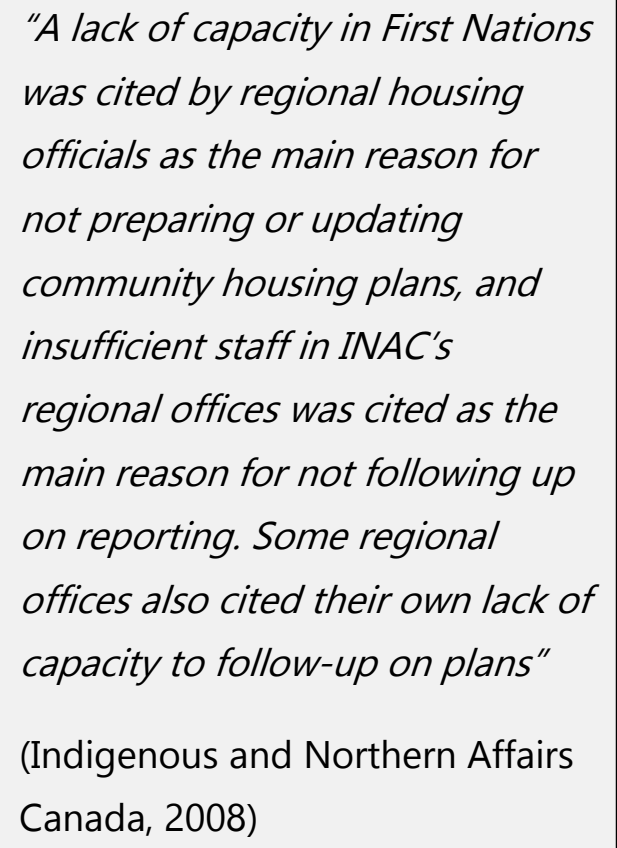

An evaluation of the 1996 On-Reserve Housing Policy released by INAC in 2008 established the important relationship between the Community Housing Plans limited success with underserved capacity.

Steps required to develop a Community Housing Plan are outlined in the document Guidelines for the Development of First Nations Housing Proposals (Indian and Northern Affairs Canada, 1996) (figure 4.1.1). This document outlines how housing plans are expected to "address where, how

and what development is going to take place over a five-year (or longer) period, including specifics for short-term development and conceptualizing long term development, as well as linkages to social and cultural goals and physical development" (Indian and Northern Affairs Canada, 1996). However as INAC's 2008 report foreshadows, the steps and processes required for a CHP can only lead to the achievement of long term objectives if supported with sufficient levels of administrative, financial and governance capacity. 
Capacity is a term which can be described as a measurable amount of a unit required to perform optimally, or the mental or physical the ability of a person or thing to complete a task competently (MerriamWebster, 2011). Discussing capacity development in the context of onreserve housing exemplifies how complex interpretations of this term can be. In an attempt to simplify the concept of capacity for the purpose of discussing Community Housing Plans, findings related to capacity were grouped by relevance to administrative, financial or governance capacity.

\section{Administrative Capacity}

The administrative skills and resources required to develop and maintain a Community Housing Plan are significant. Performing detailed housing assessments, compiling work plans, and

Community Based Housing Plan

1. a) Perform a Community Housing Assessment

b) Perform a Conditional Housing Assessment of Existing Housing

2. a) Submit a work plan which defines tasks for each year

\section{I}

b) Submit a resource plan which outlines the financial capacity of a Band

3. Indicate how housing activities will be linked with training, job creation \& business development

documenting opportunities for economic development all require analytic skillsets. Some communities have managed to significantly improve their housing systems using CHPS however it could be argued that this success depends heavily on the access of communities to appropriate expertise. Many communities lack the skilled and experienced housing managers, planners and technicians and builders needed to run and implement housing programs (MacTavish, Marceau, \& Optis, 2012). Skills and expertise of housing staff vary widely throughout reserve communities (Indigenous and Northern Affairs Canada, 2008), in particular 
there is an identified need for financial management expertise on reserve (Indigenous and Northern Affairs Canada, 2008). As such, not all communities are properly equipped to carry out the design, implementation, or long term management of responsibilities associated with creating and implementing housing plans. Furthermore if a community cannot maintain consistent administrative capacity over the lifespan of their Community Housing Plan, they may be less capable to fulfill their annual report of plan progress to the AANDC (Indian and Northern Affairs Canada, 1996) and risk losing opportunities to acquire additional funding in the future.

To establish proper administrative capacity for the creation and maintenance of housing plans, the federal government proposed training plans, programs, and facilities that would equip First Nations with necessary skills and expertise (Indian and Northern Affairs Canada, 1996). Aboriginal Affairs and Northern Development Canada promised that INAC and CMHC, in cooperation with First Nation organizations would "organize workshops, provide information and advice to help First Nations communities in the development and operation of their community-based housing programs (Indian and Northern Affairs Canada, 1996). Information was promised to cover "all aspects of housing from the development of local policies and programs to resource planning, property management, tenant counselling and innovative technologies" (Indian and Northern Affairs Canada, 1996). However the training programs provided showed a tendency "to focus on developing skills for administrative support and middle management" (The Institute on Governance, 1997). The programs trained First Nations to implement the decisions of other governments and decision makers from outside of their communities (The Institute on Governance, 1997) instead of providing education and training which would allow them take leadership roles in policy development and implementation. There 
is an urgent need to instead "train Aboriginal people to assume senior management and administrative positions in Aboriginal governments. Senior managers will need to be trained in such areas as finance, policy, and program design, planning and management" (The Institute on Governance, 1997). Downloading the responsibility of Community Housing Plans onto reserves with limited support to develop administrative capacity has highlighted several problems:

- Should a First Nation create a plan, they may in the future lack the administrative capacity to update it and maintain reporting requirements to the federal government. These efforts are further frustrated by the time-consuming and complex nature of administrative reporting systems (The Institute on Governance, 1997)

- Without proper financial training there is are heightened opportunities for the misallocation or inefficient spending of funds

- First Nation administrations must employ their limited capacity to implement a policy which lacks Indigenous perspective and cultural appropriateness. This may impede their ability to achieve other community goals and objectives

Ultimately, it should be recognized that not all First Nations have access to the same administrative capacity to develop and maintain CHPS. This consideration should be reflected within future policy structure as well as in the distribution of training programs and resources.

\section{Financial Capacity}

As few physical improvements to housing on reserve can occur without federal funding, access to finance capacity to implement successful housing plans is critical. The 1996 policy is structured to deliver funding throughout different points of policy implementation. Initially, when a First Nation joins the 1996 On-Reserve Housing Policy they receive a one-time lump sum (Indigenous and Northern Affairs Canada, 2016) to initiate the process. Funding to establish a 
Housing Program is then applied for through INAC's On-Reserve Housing Capacity

Development Fund (Indigenous and Northern Affairs Canada, 2016). This fund supports the creation of housing governance tools, financing for housing management, and housing maintenance after the implementation of a plan (Indigenous and Northern Affairs Canada, 2016). Where administrative capacity is low these funds are often used to hire outside planning firms to assist First Nations with in creating multi-year plans (Indigenous and Northern Affairs Canada, 2016). The maximum non-refundable amount First Nations can receive for all categories is $\$ 330,000$ (Indigenous and Northern Affairs Canada, 2016).

Once a First Nation community develops a basic format housing program proposal it is reviewed by Indigenous and Northern Affairs Canada (Indian and Northern Affairs Canada, 1996). If approved the First Nation then submits a final copy of the proposal with additional detailed information (Indian and Northern Affairs Canada, 1996). Only when the final proposal is accepted does it become a basis for any future funding arrangements for housing between the federal agency and the First Nation (Indian and Northern Affairs Canada, 1996). Though Community Housing Plans are meant to facilitate a streamlining of funding arrangements, the successful submission of a CHP does not mean automatic approvals for funding or programming from other major funding sources. Monetary support from capital funding, $\mathrm{CMHC}$ Section 95, Residential Rehabilitation Assistance Program allocations or training funds (Indian and Northern Affairs Canada, 1996) must be applied for separately. Though INAC and CMHC indicated that Community Housing Plans would act as a tool to identify the state of a community's housing stock to determine when new units would be built or renovated (Office of the Auditor General of Canada, 2006), the effectiveness of this technique is questionable. 
Despite the presence of some available funding, housing problems on reserve continued to exist (Office of the Auditor General of Canada, 2006). There are additional concerns regarding financial capacity:

- There is little financial incentive for First Nations to direct their limited and valuable resources towards maintaining, updating or following Community Housing Plans post plan completion

- Funding received from INAC and CMHC is often not provided in a coordinated way making it difficult for a First Nation to plan for future projects and homes (Office of the Auditor General of Canada , 2003)

- If First Nations are not guaranteed multi-year funding to implement a multi-year plan they will not be able to keep up with their annual housing goals and objectives

- Financial reports outlining federal funding allocation on-reserve are not always properly submitted or reviewed by federal agencies (Office of the Auditor General of Canada, 2003)

- There is a tendency to direct funds received on reserve to areas of critical need. This means investment often first goes into repairing existing homes rather than building new ones (Office of the Auditor General of Canada , 2003)

These factors may all contribute to why Community Housing Plans have not led to substantial new home starts, thus having limited visible impact on reserves. Streamlining funding to homes and communities experiencing crisis must therefore occur alongside the development of financial capacity. Developing financial expertise on reserve is also necessary to ensure First Nations are allocating funds efficiently and effectively. Finally, federal agencies must have the resource capacity to review submitted funding applications and follow up with financial reports. 
To foster self-governance over housing systems on reserve the federal government proposed each First Nation develop a community housing authority. Housing authorities were thought to be active contributors of the Community Housing Plan and participating community members would have the opportunity take on leadership roles, garner governance skills, and strengthen the overall accountability of First Nations governance structures (Office of the Auditor General of Canada , 2003). The role of housing authority is to "manage day to day operations and make recommendations to the Chief and Council on new or reserved housing policies, programs and plan" (Koeck, 2000). Housing authorities are also administrative entities, "intended to operate as quasi-property managers, rental agencies, make recommendations to the chief and council on new or revised housing policies and programs and plans" (Office of the Auditor General of Canada, 2011). However, the ability of housing authorities to develop meaningful governance capacity which would allow them to control housing on their reserves is undermined by the limited powers held by the Band itself. "Their capacity to act and respond to the needs of communities is still limited by the fact that Bands simply administer federal programs, they do not have the real capacity to act as they lack financial resources, jurisdiction and are both accountable to and financially dependent on the federal government" (Ladner, 2009). Bands are often "locked in funding arrangements with CMHC and INAC so they have difficulty asserting meaningful control over their housing programs" (MacTavish, Marceau, \& Optis, 2012). They are further hampered by low or declining levels of funding and a dense web of restrictions on their use of their capital and operating funds (MacTavish, Marceau, \& Optis, 2012). 
Additionally there are many small communities where there is no one assigned specifically to manage housing (Catherine Palmer \& Associates Inc., 2007). "In cases where there is no housing department, one person is usually assigned to be the maintenance clerk, administrative assistant, housing coordinator, proposal writer, and even sometimes the Band Manager. Housing issues therefore continued to be managed instead of ever getting resolved because there is no one with time, energy, or enough money to make any meaningful changes" (Catherine Palmer \& Associates Inc., 2007).

The placement of Band councils and housing authorities in this difficult position may explain in part why Community Housing Plans have not fostered meaningful self-governance on reserve. There are additional implications for First Nation communities:

- Without granting a Band the appropriate legislative governance powers, powers of housing authorities in community planning are inherently undermined

- The short two year terms of Band Chiefs and Councils may frustrate the long term vision of a multi-year plan if elected officials have different opinions about the goals and objectives for community housing (Joseph, 2015)

These findings suggest the presence of a capable housing authority and support of Band Council is critical to implementing successful housing plans however they must have the proper legislative powers and governance capacity tools to do so.

Developing sufficient levels of administrative, financial and governance capacity on-reserve is no-doubt a complex task. Each one contributes to the ability of a First Nation to successfully implement Community Housing Plans, as well as achieve higher level objectives of the 1996 OnReserve Housing Policy. 


\subsection{The Big Letdown of Federal Support}

Findings from this research illustrate that First Nations are confronted with significant barriers to realize the capacity to create and benefit from Community Housing Plans. It could be argued that even with unlimited access to administrative expertise, funding, training and strong governance capacity through their Band Councils and Housing Authorities, Band would still be unsuccessful. This is due to a serious lack of dedicated support by the federal government to the agencies that provide capacity development on reserves and hold important roles in managing Community Housing Plans. An appropriate Department (INAC) staff and resources required to oversee on-reserve housing programs were under provided due to severe oversight by the Department (INAC) (Office of the Auditor General of Canada, 2003). Since the inception of the policy the Department was insufficiently prepared to properly review housing plans submitted by First Nations, monitor their implementation and properly co-ordinate and allocate funds to complete these tasks (Office of the Auditor General of Canada, 2003). A status report released in 2011 noted an overall lack of organization between the two departments (INAC \& CMHC) to support service delivery on reserves (Office of the Auditor General of Canada, 2011). A later audit assessing capacity development programming on reserve conducted by the Audit and Assurance Services Branch confirmed that "AANDC lacked a coordinated, risk-based, strategic approach to the design, delivery and implementation of capacity development programming" (Aboriginal Affairs and Northern Development Canada, 2013). Overall, there is evidence to show that that any efforts made by federal agencies to develop capacity on-reserve have yielded positive results (Aboriginal Affairs and Northern Development Canada, 2011). In a review of the performance of the 1996 policy conducted in 2008, INAC stated that "much remains to be done 
by all partners to build the range of capacities First Nations need to manage their housing regimes effectively" (Indigenous and Northern Affairs Canada, 2008). It is a disconcerting thought that while First Nations are expected to meet the high expectations associated with Community Housing Plans, federal agencies themselves are not properly equipped to uphold their role in the process. A role which holds control over the capacity development programming, funding allocation, and plan reporting for CHPs.

\subsection{A Critique of Community Housing Plans}

The presence of "insufficient funding, high rates of managerial turnover, understaffed administration, lack of specialized trades and engineering, and gaps in occupant education and responsibility" (Kyser, 2012) are evidence of underserved capacity which bar the attempts of First Nations to implement and maintain housing plans on reserves. First Nations are not provided with alternative options for community growth or capacity development apart from the Community Housing Plans yet twenty years later, evaluations still report that many communities were still not submitting, updating or implementing their housing plans in full accordance with the 1996 on-reserve housing policy (Aboriginal Affairs and Northern Development Canada, 2011). Though $\mathrm{CMHC}$ has slowly begun delivering training to First Nations' housing providers (Office of the Auditor General of Canada, 2006), First Nations still struggle to develop and use their housing plans as they are intended (Office of the Auditor General of Canada , 2003). Regional officials have cited a lack of capacity "as the main reason for communities not preparing or updating community housing plans" (Aboriginal Affairs and Northern Development Canada, 2011). 
The reoccurring presence of Community Housing Plans in federal audit recommendations waves red flags about its ability contribute to the overall effectiveness of the 1996 On-Reserve Housing Policy. This policy which, upon reflection of several years of recommendations to improve the living conditions of First Nations has observed little measurable improvement (Assembly of First Nations, 2012). Spreading thin administrative, financial and governance capacity and resources across a large area of need dilutes the ability of a Band and community to sufficiently tackle any aspect of their housing crisis in a meaningful way (Belanger, 2016). To further complicate matters, capacity available to First Nations (especially those on smaller reserves), is not proportional to capacity needed to fulfill complex policy requirements such as Community Housing Plans. Despite the objectives outlined with the release of the 1996 policy, First Nations are still asking for help to build capacity on their reserves (Aboriginal Affairs and Northern Development Canada, 2011). 


\section{Decolonizing On-Reserve Planning and Policy}

Community Housing Plans are a western construct used to guide land-use on First Nation reserves. As it is imposed and regimented through federal policy, its role in decolonizing housing systems merits discussion. To begin decolonizing planning and policy practices, it must first be recognized that past policy and planning actions have weakened the identity of Indigenous Peoples by "suppressing their language and cultures, and outlawing spiritual practice" (Indian and Northern Affairs and Northern Development Canada, 1997). It is "a remarkable tribute to the strength and endurance of Aboriginal people that they have maintained their historic diversity and identify" (Indian and Northern Affairs and Northern Development Canada, 1997). While the policies of the past have impoverished First Nations by deconstructing traditional governance structures and manipulating their relationship to land and home, current laws and policies maintain these conditions (Palmater, 2011). If the state of housing conditions on reserves is considered as an output of federal policy, contributing to the movement of people away from First Nation communities and into Canadian cities, it could be argued that housing policy is still a direct contributor to the ongoing assimilation of Indigenous Peoples (Monk, 2013).

The approach of incorporating local planning into First Nations communities through Community Housing Plans was based on principles of community control, capacity development, shared responsibility, and improving access to investment (Indian and Northern Affairs Canada, 1996). Housing Plans have been praised for their incorporation of Indigenous Planning into the community planning process however "in order to adhere to this definition, when developing a community housing plan, members of the community and Chief and Council 
need to control the planning process by acting as key players in the creation of the community housing plan" (Mbadugha, 2013). If the administrative, financial and governance capacity available on a reserve is not present to undertake the creation of a housing plan, plans instead become the product of western consulting firms, deficient in the incorporation of Indigenous perspectives (Belanger, 2016) and can no longer be classified as outputs of Indigenous planning. By nature the structure of housing plans lack an adequate appreciation for long term vision of the reserve (Millette, 2011) and they continue to prolong the tendency for First Nations to organize and develop their communities based on settler style model of community design (Monk, 2013).

Infusing Indigenous identity into policy and processes is necessary to reconfigure current approaches and outcomes. It is an alternative to the current approach of simply managing the housing crisis as opposed to finding a long-term solution (Belanger, 2016). Moving forward planners must learn from the intersection between Community Housing Plans and Indigenous planning (Mbadugha, 2013), and recognizing "planning's involvement in the dispossession, oppression, and marginalization of Indigenous peoples has important implications for the field" (Ugarte, 2014). This is a unique opportunity to develop awareness around the ways First Nation communities have been able to plan their surroundings, lands and resources to meet their particular needs (Mbadugha, 2013).

The 1996 On-Reserve Housing Policy requirement for Community Housing Plans continues to unveil conflicting cultural views (Monk, 2013). In rethinking the existing approach, "there is a defensible reason to involve Aboriginal peoples as co-producers of plans and policies" (Belanger, 2016) and a recognition of the very "different historical, political and cultural realities 
within the First Nation reserve contexts in Canada" (Millette, 2011). The role of outside planners can be dedicated to providing advice, funding and technical expertise as First Nations take ownership over planning in their communities, but their role is not to solve housing problems in First Nation communities (Graham \& Motsi, 2008).

The output of on-reserve housing policy can no longer be reduced to the provision of four walls physical walls and a roof (Kyser, 2012). Policy should instead be viewed as an opportunity to shift First Nations communities from being recipients of programming, to actively partaking in the design and development of housing systems in their communities (McCartney, 2016). If housing plans can be created through Indigenous planning (Jojola, 2008) to both prioritize the current and future needs and appreciate a First Nations unique experience and situation (Mbadugha, 2013), perhaps the process of de-colonizing housing policy on reserve can begin. (Monk, 2013). 


\section{Conclusion}

This study of the relationship between First Nation capacity and Community Housing Plans reveals wide implications for both the current federal strategy as well as for the field of planning.

The Community Housing Plan is just one of many complex housing tasks downloaded to First Nations. If capacity is unsupported for just one of the four founding elements of the 1996 OnReserve Housing Policy there is grounds to discuss the possible implications this absence has in others. A review of evaluative reports provides evidence that federal agencies have not ensured they are capable of supporting First Nations as they transfer control of housing systems to First Nation Bands, Councils and housing authorities. On-reserve housing policy requirements have not been sufficiently met with appropriate administrative, financial or governance capacity to properly enact housing programs on their reserves. All efforts made are undermined by the lack of commitment by the federal government to provide sufficient capacity to federal agencies responsible for regulating Community Housing Plans and distributing funding. The following recommendations should serve as a guide for future research and policy development:

\section{Administrative Capacity:}

- $\quad$ First Nations must be provided with suitable administrative capacity prior to the implementation of policy. Furthermore, and First Nations should have a clear understanding of the requirements and capacity necessary to complete tasks, including long-term commitments.

- To develop administrative capacity on reserve training programs dedicated to building administrative bodies in First Nation communities should focus on building leadership roles in policy development and implementation. 
Financial Capacity

- Federal funding must be streamlined to work in conjunction with multi-year housing plans, therefore funding must also be dedicated for a multi-year periods. $\mathrm{CMHC}$ and INAC must coordinate efforts alongside First Nations to ensure that funding is received and allocated appropriately with simplified reporting requirements.

- To develop financial capacity on reserve First Nations should be trained to gain financial expertise to ensure funds are distributed and utilized efficiently, as well as plan for the fiscal future of their communities.

\section{Governance Capacity}

- To develop governance capacity on reserve First Nation Bands should be granted additional legislative powers to have greater control over future housing policy functioning on reserve and grant housing authorities with greater control over housing systems.

This research also discusses the role of on-reserve housing policy in perpetuating practices of colonization and assimilation by designing and administering the regulations which determine the relationship between First Nations, land and home. Researchers and planners working within this field of planning are therefore encouraged to:

- Recognize the unique circumstances experienced by First Nations communities. Each "is distinctive in its particular history, tradition and needs and all require specific planning" (University of Manitoba, n.d.). This recognition is the first step through which federal policies can identify and provide resources dedicated to building community capacity as a condition to improving housing on-reserve (University of Manitoba, n.d.).

- Encourage opportunities in the field of planning to assist in closely analyzing, criticizing and re-defining relationships between policy makers and First Nations communities to work towards the decolonization of Indigenous policy. This requires a shift whereby 
policy is focused on "community-level values instead of state-based solutions" (Senate Canada, 2015).

Housing issues on reserve pose complex problems for policy makers and First Nations however, the greatest weakness of the current policy approach is the absence of First Nation perspective in policy design. Adopting Indigenous planning will be essential in the future development of First Nation communities as they continue to grow and hopefully one day prosper. The role of housing policy as well as the traditional role of the planner on-reserve must be re-imagined, assisting and walking alongside First Nations communities as they develop and grow the capacity needed to self-govern housing systems in their communities. 


\section{References}

Aboriginal Affairs and Northern Development Canada. (2011). Evaluation of INAC's On-Reserve Housing Support. Archived Information. Project Number 1570-7/07068: Evaluation Performance Measuremenet Branch Audit and Evaluation Sector.

Aboriginal Affairs and Northern Development Canada. (2012). History: Aboriginal Peoples. Retrieved from Aboriginal Affairs and Northern Development and the Treaty Relationship: https://www.aadnc-aandc.gc.ca/eng/1338907166262/1338907208830

Aboriginal Affairs and Northern Development Canada. (2013). Follow-Up Audit of Capacity Development. Internal Audit Report. Audit and Assurances Branch.

Akin, D. (2016, September 25). Ottawa Makes Tiny Dent in Massive Demand for First Nations Housing. National Post.

Assembly of First Nations. (2005). First Nation Housing Action Strategy (Draft). Retrieved from Assembly of First Nations: Retrieved from: http://www.afn.ca/uploads/files/aga2013/draft_fn_housing_strategy_e.pdf

Assembly of First Nations. (2010). First Nations Guide to Housing Policy. Retrieved from http://www.afn.ca/uploads/files/housing/housing-policy-guide.pdf

Assembly of First Nations. (2012). 2012 First Nations Plan: Honouring our Past, Affirming our Rights, Seizing our Future. Crown.

Belanger, Y. D. (2016). A Critical Review of First Nations and Aboriginal Housing Policy, 1867 Present. In C. D. Eds. Naomi Nichols, Exploring Effective Systems Responses to Homelessness (pp. 443-455). Toronto, ON: Canadian Observatory on Homelessness.

Brant, D. (2000). Successful Housing in First Nation Communities. A Report on Community Case Studies. Socio-Economic Policy and Programs.

Camfield, D., \& Woroniak, M. (2013). First Nations Rights: Confronting Colonialism in Canada. Retrieved from Centre for Research on Globalization: http://www.globalresearch.ca/firstnations-rights-confronting-colonialism-in-canada/5321197

Canada Mortgage and Housing Corporation. (1991). What we Heard. Report on the Rural and Native Housing Consultation Process. Canada: Public Affairs Centre, CMHC.

Canada Mortgage and Housing Corporation. (2005). Aboriginal Housing. Local Materials and Design Preferences. Publications and Reports. 
Canada Mortgage and Housing Corporation. (2011). 2011 Census/National Household Survey. Housing Conditions On-Reserve Aboriginal Households. Housing Conditions Series.

Canada Mortgage and Housing Corporation. (2015). Federal Government Spending on Housing. Retrieved from Canada Mortgage and Housing Corporation: https://www.cmhcschl.gc.ca/en/corp/nero/jufa/jufa_016.cfm

Catherine Palmer \& Associates Inc. (2007). Aboriginal Housing In British Columbia. Needs and Capacity Assessment: Final Report.

First Nation Information Governance Centre. (2008). First Nation Regional Health Survey. National Report on Adults, Youth and Children living in First Nations communities. Ottawa.

Graham, J., \& Motsi, G. (2008). How to Improve First Nations Housing . 2008: Patterson Creek Consulting .

Hill, C. W. (2010). Aboriginal Housing in Canada: An Informal Background Discussion Paper. Vancouver, BC: Canadian Aboriginal AIDs Network.

Hutchins, P., \& Hutchins, S. \&. (2002). The Quest to Slay the Indian Act: An Impossible Dream? Toronto : Pacific Business \& Law Institue.

Indian and Northern Affairs and Northern Development Canada. (1997). Gathering Strength. Canada's Aboriginal Action Plan. Ottawa: Minister of Public Works and Government Services Canada.

Indian and Northern Affairs Canada. (1996). Guidelines for the Development of First Nations Housing . Retrieved from Government of Canada: http://publications.gc.ca/collections/collection_2016/aanc-inac/R5-85-1996-eng.pdf

Indigenous and Northern Affairs Canada. (1990). Laying the Foundations of a New On-Reserve Housing Program. Discussion Paper. Ottawa: Indigenous and Northern Affairs Canada.

Indigenous and Northern Affairs Canada. (2008). Evaluation of the 1996 On-Reserve Housing Policy. Ottawa: Audit and Evaluation Sector. Evaluation, Performance Measurement and Review Branch.

Indigenous and Northern Affairs Canada. (2011). Aboriginal Demographics from the 2011 National Household Survey. Planning Research and Statistics Branch.

Indigenous and Northern Affairs Canada. (2011). Governance and Capacity Tool. Retrieved from Government of Canada: https://www.aadncaandc.gc.ca/eng/1314982906753/1314983007320 
Indigenous and Northern Affairs Canada. (2016). First Nations People in Canada. Retrieved from Government of Canada: https://www.aadncaandc.gc.ca/eng/1303134042666/1303134337338

Indigenous and Northern Affairs Canada. (2016). On-Reserve Housing Capacity Development Fund Guidelines. Retrieved from Government of Canada: https://www.aadncaandc.gc.ca/eng/1464808400088/1464808436882

Indigenous and Northern Affairs Canada. (2016). Ontario Region. Retrieved from Government of Canada : https://www.aadnc-aandc.gc.ca/eng/1100100020284/1100100020288

Indigenous and Northern Affairs Canada. (2016). Treaties with Aboriginal People in Canada. Retrieved from Government of Canada: https://www.aadncaandc.gc.ca/eng/1100100032291/1100100032292

Jojola, T. (2008). Indigenous Planning: An emerging context. Canadian Journal of Urban Research Vol $17(1), 37-47$.

Joseph, B. (2015). Indian Act and Elected Chief and Band Council System. Retrieved from Working Effectively with Indigenous Peoples: http://www.ictinc.ca/blog/indian-act-and-elected-chiefand-band-council-system

Koeck, N. (2000). On Reserve Housing Policy Impact Assessment 1996-2000. Prepared for Community Infrastructure and Housing Directorate Department of Indian Affairs and Northern Development. Blue Heron Consulting Services.

Kyser, J. F. (2012). Improving Aboriginal Housing: Culture and Design Strategies. Calgary, AB: Thesis. Faculty of Environmental Design, Calgary.

Ladner, K. (2009). Understanding the Impact of Self-Determination on Communities in Crisis. Journal de la Santé Autochtone. National Aboriginal Health Organization Vol 5(2).

MacTavish, T., Marceau, M., \& Optis, M. (2012). A Participatory Process for the Design of Housing for a First Nations Community. Policy and Practice. J House and the Built Environ, 207-224.

Mbadugha, M. C. (2013). Indigenous Planning: Process and Development of a Community Housing Plan for Swan Lake First Nation. University of Manitoba: Practicum submitted to the Faculty of Graduate Studies.

McCartney, S. (2016). Re-Thinking Housing: From Physical Manifestation of Colonial Planning Policy to Community Focused Networks. Urban Planning. Vol 1(4), 20-31. 
Merriam-Webster. (2011). Capacity. Retrieved from Miriam.Webster.com:

http://www.learnersdictionary.com/definition/capacity

Millette, D. (2011). Land Use Planning on Aboriginal Lands - Towards a New Model for Planning on Reserve Lands. Canadian Journal of Urban Research Vol 20(2), 20-35.

Milloy, J. (2008). Indian Act Colonialism: A Century Of Dishonour, 1869-1969. Research Paper for the National Centre for First Nations Governance.

Missens, R. (2008). Sovereignty, Good Governance and First Nations Human Resources: Capacity Challenges . National Centre for First Nations Governance.

Monk, L. (2013). Decolonizing Home: A Re-Conception of First Nations' Housing in Canada. Victoria, BC: Universtiy of Victoria.

Office of the Auditor General of Canada. (2003). Chapter 6. Federal Government Support to First Nations - Housing on Reserves. 2003 Report of the Auditor General of Canada to the House of Commons.

Office of the Auditor General of Canada. (2006). Chapter 5. Management of Programs for First Nations. Report of the Auditor General of Canada to the House of Commons.

Office of the Auditor General of Canada. (2011). Chapter 4: Programs for First Nations on Reserves. Status Report of the Auditor General of Canada to the House of Common.

Palmater, P. (2011). Stretched Beyond Human Limits: Death by Poverty in First Nations. Canadian Review of Social Policy, 112-127.

Perry, A. (2003). From "the hot-bed of vice" to the "good and well-ordered Christian home": First Nations Housing and Reform in Nineteenth-Century British Columbia. Ethnohistory, Vo/ 50(4), 587-610.

Reading, C., \& Wien, F. (2009). Health Inequalities and Social Determinents of Aboriginal Peoples' Health. National Collaborating Centre for Aboriginal Health.

Senate Canada. (2015). Housing on First Nations Reserves: Challenges and Successes. Interim Report of the Standing Senate Committee on Aboriginal.

Shneider, L. (1992). A Time for Action. Aboirignal and Housing Standing Committee of Aboriginal Affairs. Ottawa: Queens Printer.

The Canadian Encyclopedia. (2016). Indigenous Peoples. Retrieved from The Canadian Encyclopedia: http://www.thecanadianencyclopedia.ca/en/article/aboriginal-people/ 
The Institute on Governance. (1997). Developing Capacity for Program Management: Summary of the Major Conclusions of the Royal Commission on Aboriginal Peoples. Ottawa: The Institute on Governance.

Ugarte, M. (2014). Ethics, Discourse, or Rights? A Discussion about a Decolonizing Project in Planning. Journal of Planning Literature. Vol. 29(4), 403-414.

University of British Columbia . (2009). Terminology. Retrieved from Indigenous Foundations. First Nations \& Indigenous Studies:

http://indigenousfoundations.arts.ubc.ca/home/identity/terminology.html

University of Manitoba. (n.d.). On-Reserve Housing. Retrieved from University of Manitoba: http://www.umanitoba.ca/architecture/cp/app/sections/issues/other/housing/conclusions.ht $\mathrm{ml}$ 


\section{Glossary of Terms}

AANDC: Aboriginal Affairs and Northern Development Canada

AFN: Assembly of First Nations

CHP: Community Housing Plan

CMHC: Canada Mortgage and Housing Corporation

INAC: Indian and Northern Affairs Canada; formerly DIA: Department of Indian Affairs; Formerly DIAND

RCAP: Royal Commission on Aboriginal Peoples

RRAP: Residential Rehabilitation Assistance Program 